\title{
Niche conservatism of Eulophia alta, a trans-Atlantic orchid species
}

\author{
Marta Kolanowska*, Dariusz L. Szlachetko \\ Department of Plant Taxonomy and Nature Conservation, University of Gdańsk, Wita Stwosza 59, 80-308 Gdańsk-Oliwa, Poland
}

\begin{abstract}
The genus Eulophia embraces over 230 species distributed through the tropical and subtropical Africa, Asia, Australia and the Americas. In Neotropics it is represented by a sole species $-E$. alta. The aim of the presented study was to evaluate the difference between ecological niches occupied by American and African populations of this species based on the ecological niche modeling. The similarity between the glacial and present niches occupied by E. alta was calculated and the factors limiting the species occurrence were identified. Areas of seasonal tropical forest, tropical savanna and woodland served as refugia for the studied species during last glacial maximum and they were more widespread in Neotropics than in Africa. No significant niche shift after last glacial maximum was observed. The distribution of $E$. alta in its whole range is restricted mainly by temperature seasonality. The differences in the niches occupied by African and Neotropical populations of E. alta suggest preglacial disjunction of the species range and independent adaptation of both groups. Despite the significant range disjunction of $E$. alta the species is characterized by relatively high degree of niche conservatism.
\end{abstract}

Keywords: ecological niche modeling; last glacial maximum; Orchidaceae; trans-Atlantic disjunction

\section{Introduction}

The trans-Atlantic range disjunction is observed within about 110 angiosperm genera [1]. Despite over 40 years of biogeographical studies [2-4] the understanding of timing, direction and pattern of long-distance dispersal across the Atlantic is still very limited. Little is known also about the niche variation of the taxa characterized by remarkable distribution gap.

The niche conservatism of numerous organisms was recently intensively studied using ecological niche modeling (ENM) methods [5-7], but so far this analysis was not apply to evaluate niche variation of species exhibiting trans-Atlantic disjunction. Based on the incoming research results it is difficult to formulate any explicit principle about the tendency of such species to retain characteristics of their fundamental niche over time. The degree of niche conservatism varies among groups of species (small-ranged and specialist [6]) and it is related to the evolutionary history of each taxon [8]. While some authors [9] considered evolutionary and biogeographic patterns of species diversity as completely separated processes, the concept of niche conservatism offers a bridge between them [10-13]. Studies on ecological niche variation are particularly important to recognize fundamental distribution factors and evolutionary models of species characterized by the disjunctive

\footnotetext{
* Corresponding author. Email: martakolanowska@wp.pl
}

Handling Editor: Aleksandra Samecka-Cymerman range. While in some taxa the geographical discontinuity resulted in adaptive [14,15], other adjusted evolutionary stable strategy [16].

The object of our study was Eulophia alta (L.) Fawc. \& Rendle, a sole representative of the genus in Neotropics where its range extends from USA (Florida) south to Argentina. Except Americas E. alta occurs in the Africa, from Senegal to Zimbabwe and it is assumed that it originates in the Old World where high specific diversity of the genus is observed. However, no clear evidence of this hypothesis was presented so far. Eulophia alta is terrestrial, large plant producing a subglobose, subterranean corm and loosely many-flowered, racemose inflorescence. The species is found in open areas, along roadsides and on cleared land reverting to bush lower montane forest, usually in heavy, moisture-retentive soils. Populations of $E$. alta were found in lowland and premontane areas, at the altitudes up to $1500 \mathrm{~m}$. The main flower visitors and most effective pollinators of this species are anthophorid bees. Six Hymenopteran and two Lepidopteran families were observed visiting the flowers [17].

The aim of this study was to evaluate the similarity of the niches occupied by African and Neotropical populations of E. alta using ENM tools. Because adaptation to local climatic conditions is a significant force driving morphological evolution and speciation, the availability of the suitable niches of the studied species during last glacial maximum (LGM; 26 500-19000 years ago) was evaluated to estimate the possible postglacial niche shift and geographical range changes of $E$. alta. In the studies on Orchidaceae the ENM was applied so far mainly in the research on invasive species [18,19] and 
a sole analysis [20] concerned the potential distribution of orchid during last glacial maximum.

\section{Material and methods}

\section{Localities and georeferencing}

The database of E. alta localities was prepared based on the examination of herbarium specimens deposited in herbaria AMES, BM, BR, COL, HUA, K, MO, NY, P, UGDA, VALLE, W, and WAG. Herbaria acronyms are cited according to "Index Herbariorum" [21]. To enlarge the dataset, the information obtained from the electronic database of the Missouri Botanical Garden (available at http://www. tropicos.org) was included in the analysis.

The georeferencing process followed Hijmans et al. [22] and only the localities, which could be precisely placed on the map were used in the study. The information about the latitude and longitude provided on the herbarium sheet labels were verified. If no geographic coordinates were indicated by the plant collector, they were assigned based on the data about the collection place. The Google Earth (v. 6.1.0.5001, Google Inc.) application was used to validate all gathered information.

In total 54 localities were included in the database (Fig. 1, Tab. 1), 8 African and 46 Neotropical, which is more than the minimum number of localities $(>5)$ required by Maxent to obtain reliable predictions [23].
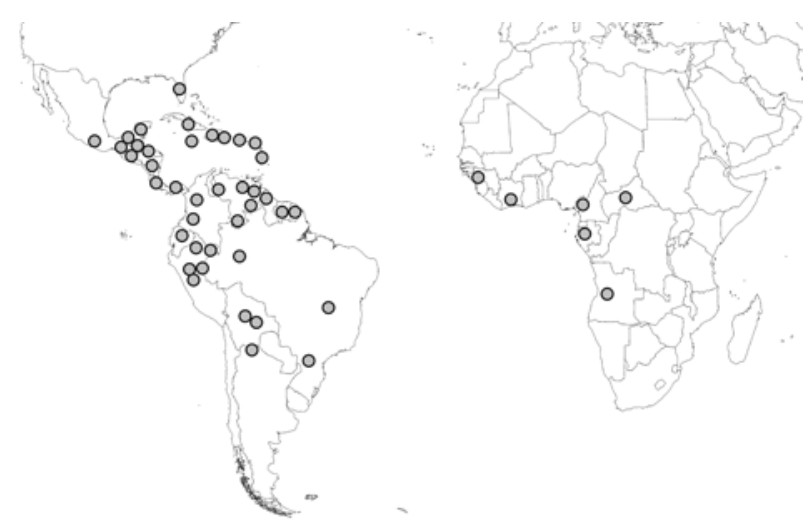

Fig. 1 Locations of E. alta used in the ecological niche modeling.

\section{Maximum entropy analysis}

The maximum entropy method implemented in Maxent version 3.3.2 [24-26] was used to create models of the distribution of the ecological niches of E. alta. Because Maxent is relatively robust against collinear variables [27,28], all available climatic factors (Tab. 2) in 2.5 arc-minutes developed by Hijmans et al. [29] as well as the altitudinal data were used as an input data. This was also justified by the insufficient data on habitat requirements of the studied species that could lead to premature exclusion of the correlated variables. The analogical bioclimatic data for the last glacial maximum period was mapped by Paleoclimate Modelling Intercomparison Project Phase II [30].
To assess high specificity of the modeling, the maximum iterations was set to 10000 and convergence threshold to 0.00001 . For each run $20 \%$ of the data were used to be set aside as test points [31]. The "random seed" option which provided random test partition and background subset for each run was applied. The run was performed as a bootstrap with 100 replicates, and the output was set to logistic. All operations on GIS data were carried out on ArcGis 9.3 (ESRI).

\section{Niche similarity}

The geographical overlap of the niches calculated based on two different datasets (African and Neotropical locations only) as well as the similarity of niches occupied by the populations from the New World and Africa were defined based on the test implemented in ENMTools application. The Schoener's $D$ [32] and $I$ [33] statistics were calculated. In Schoener's $D$ statistic the local species density measures are compared with each other. "I" statistic is based on Hellinger distance and measures the ability of the model to estimate the true suitability of the habitat. Both metrics range from 0 (no similarity) to 1 (overlapping).

\section{Results}

\section{Models evaluation}

All repeated ecological niche models for the present time received high area under the curve (AUC) scores of $0.972-0.984$ (Tab. 3) that indicate very high reliability of the analysis.

\section{Bioclimatic limiting factors}

The results of the niche modeling indicated three main bioclimatic variables limiting the distribution of suitable habitats for E. alta. The crucial factor is the temperature seasonality (bio4), which influenced significantly models of both African and Neotropical populations of the studies species. While the range of latter geographical group is also related with the amount of precipitation in the coldest quarter (bio19), the African plants are more dependent on the mean temperature of the coldest quarter (bio11). The estimates of relative contributions of the environmental variables to the Maxent model for both present time and LGM are presented in Tab. 4.

\section{Potential glacial refugia}

The model of habitats available in Neotropics during the LGM indicate few possible glacial refugia of E. alta (Fig. 2). In Mesoamerica the suitable niches were located in the Gulf of Honduras, Mosquitia lowlands, Mosquito Coast, Cordillera de Talamanca, the Darién Gap as well as in Jamaica. In South America the possible glacial refugia were located in the northern Andes, eastern pre-Andean highland and partially Amazon basin, Guiana Highlands as well as western Brazilian coast. The African refugia were much more limited and there were distributed in the northern Grain Coast and around the Gulf of Guinea. Less suitable habitats were located in the Zanzibar Archipelago and northern Madagascar. The areas determined for both, African and Neotropical populations, 
Tab. 1 Localities of Eulophia alta used in ENM analysis.

\begin{tabular}{|c|c|c|c|c|}
\hline Country & Latitude & Longitude & Collector and number & Institution \\
\hline Angola & -9.553333333 & 16.3475 & Mechow 344 & W-R \\
\hline Angola & 9.132777778 & 14.77194444 & Welwitsch 664 & $\mathrm{BM}, \mathrm{K}, \mathrm{W}-\mathrm{R}$ \\
\hline Belize & 16.99666667 & -88.40694444 & Percy H. Gentle 9262 & $\mathrm{MO}$ \\
\hline Belize & 17.09944444 & -88.32388889 & William A. Schipp S-171 & AMES, MO \\
\hline Belize & -17.74166667 & -63.2 & Michael H. Nee 48842 & NY \\
\hline Bolivia & -14.75055556 & -61.14361111 & A. Carrión, M. Castro \& V. Ayala 503 & MO \\
\hline Bolivia & -17.65 & -63.16666667 & Nur Ritter 2782 & $\mathrm{MO}$ \\
\hline Bolivia & -14.75055556 & -61.14361111 & A.M. Carrión, M. Castro \& V. Ayala 503 & MO, USZ \\
\hline Cameroon & 3.8 & 10.11666667 & Sanford 5177 & $\mathrm{~K}$ \\
\hline Cameroon & 4.966666667 & 8.85 & Thomas 2316 & $\mathrm{~K}, \mathrm{P}, \mathrm{MO}$ \\
\hline Cameroon & 18.83333333 & -69.56666667 & Thomas A. Zanoni \& Milcíades M. Mejía 16316 & $\mathrm{MO}$ \\
\hline Caribbean & 18.15 & -77.23333333 & Alwyn H. Gentry \& Valerie Kapos 28306 & MO \\
\hline Caribbean & 6.666666667 & -74.86666667 & Ricardo Callejas, Julio C. Betancur B. \& Omar D. Escobar 9020 & HUA \\
\hline $\begin{array}{l}\text { Central African } \\
\text { Republic }\end{array}$ & 6.394444444 & 21.59888889 & Le Testu 4779 & $\mathrm{BM}, \mathrm{K}$ \\
\hline Colombia & 3.840277778 & -76.89777778 & Kolanowska 233 & UGDA \\
\hline Colombia & 3.881111111 & -76.33888889 & Paz 1476 & VALLE \\
\hline Colombia & 26.01386 & -72.76 & D. Cárdenas \& R. López 6632 & COL \\
\hline Colombia & 8.73 & -83.4 & Álvaro Fernández 401 & $\mathrm{CR}$ \\
\hline Costa Rica & 8.74 & -83.56 & Gerardo Herrera Ch. 4558 & $\mathrm{CR}$ \\
\hline Costa Rica & -2.883333333 & -78.35 & B. Løjtnant \& Ulf Molau 14510 & AAU \\
\hline Ecuador & -0.466666667 & -76.91666667 & L. Broder, Holm-Nielsen, Jaramillo J. \& Coello F. 19607 & $\mathrm{MO}$ \\
\hline Ecuador & -0.466666667 & -76.91666667 & L.B. Holm-Nielsen \& et al. 19607 & AAU, MO \\
\hline Ecuador & 0.033333333 & -77.38333333 & Benjamin Øllgaard 99651 & AAU \\
\hline Ecuador & 15.50833333 & -87.45 & John M. MacDougal, Paul R. House \& Ramón Zúñiga 3276 & $\mathrm{MO}$ \\
\hline Gabon & 0.408055556 & 9.4475 & Le Testu 8669 & $\mathrm{BM}$ \\
\hline Guinea & 10.62722222 & -9.713611111 & Adam 12539 & $\mathrm{~K}$ \\
\hline Guyana & 3.35 & -59.56666667 & Jansen-Jacobs, ter Welle, Gorts-van Rijn \& Ek 670 & $\mathrm{~K}$ \\
\hline Honduras & 19.13944444 & -89.32944444 & Esteban M. Martínez S., Demetrio Alvarez M. \& Santiago Ramírez A. 28639 & MO \\
\hline Ivory Coast & 4.95 & -6.066666667 & de Wilde 358 & $\mathrm{~K}, \mathrm{WAG}$ \\
\hline Mexico & 17.35 & -100.4 & Otto Nagel 2045 & $\mathrm{MO}$ \\
\hline Mexico & 12.01666667 & -85.15 & Alfonso H. Heller s.n. & MO database \\
\hline Nicaragua & 9.168611111 & -79.85194444 & Thomas B. Croat 7788 & $\mathrm{MO}$ \\
\hline Panama & 9.168611111 & -79.85194444 & Thomas B. Croat 12809 & $\mathrm{MO}$ \\
\hline Panama & 9.169444444 & -79.85416667 & Thomas B. Croat 4391 & $\mathrm{MO}$ \\
\hline Panama & 8.6 & -80.13333333 & Paul H. Allen 1988 & $\mathrm{MO}$ \\
\hline Panama & 7.75 & -77.66666667 & Gordon McPherson 15038 & $\mathrm{MO}$ \\
\hline Panama & 7.73 & -80.87361111 & Barry E. Hammel 4243 & $\mathrm{MO}$ \\
\hline Panama & 9.100555556 & -79.27777778 & James A. Duke 5930 & MO \\
\hline Panama & 9.266666667 & -78.95 & H.W. Churchill 3814 & $\mathrm{MO}$ \\
\hline Panama & 9.266666667 & -78.95 & H.W. Churchill 3815 & $\mathrm{MO}$ \\
\hline Panama & 8.875277778 & -79.78777778 & Paul H. Allen 2080 & $\mathrm{MO}$ \\
\hline Panama & 9.365555556 & -78.95 & Gordon McPherson 11863 & $\mathrm{MO}$ \\
\hline Panama & 9.3 & -78.975 & Greg C. de Nevers \& Heraclio Herrera 4353 & $\mathrm{MO}$ \\
\hline Panama & -26.07611111 & -56.85 & Elsa M. Zardini 12678 & MO, PY \\
\hline Paraguay & -5.118888889 & -78.32083333 & Philip J. Barbour 4356 & $\mathrm{MO}$ \\
\hline Peru & -10.75 & -74.38333333 & D.N. Smith 6875 & $\mathrm{MO}$ \\
\hline Peru & -4.568055556 & -78.19805556 & Rodolfo Vásquez \& et al. 24292 & $\mathrm{MO}$ \\
\hline Peru & -3.8 & -73.41666667 & Rodolfo Vásquez \& Nestor Jaramillo 4953 & MO \\
\hline Peru & -3.746944444 & -73.40861111 & Rodolfo Vásquez \& Rocío Rojas 22731 & $\mathrm{MO}$ \\
\hline Peru & -5.083333333 & -73.83333333 & Rodolfo Vásquez \& Nestor Jaramillo 4804 & $\mathrm{MO}$ \\
\hline Peru & -11.91666667 & -77.3 & Percy Núñez V., J. Terborgh \& et al. 14246 & $\mathrm{MO}$ \\
\hline Peru & -10.75 & -74.38333333 & David N. Smith 6875 & $\mathrm{MO}$ \\
\hline Peru & -5.866666667 & -77.21666667 & David N. Smith 5963 & $\mathrm{MO}$ \\
\hline Peru & -8.75 & -75.08333333 & David N. Smith \& et al. 1187 & $\mathrm{MO}$ \\
\hline
\end{tabular}


Tab. 2 Variables used in the modeling.

\begin{tabular}{ll} 
Code & Variable \\
\hline bio1 & Annual mean temperature \\
bio2 & $\begin{array}{l}\text { Mean diurnal range }=\text { mean of monthly (max temp }- \text { min } \\
\text { temp) }\end{array}$ \\
bio3 & Isothermality (bio2/bio7) $\times 100$ \\
bio4 & Temperature seasonality (standard deviation $\times 100)$ \\
bio5 & Max temperature of warmest month \\
bio6 & Min temperature of coldest month \\
bio7 & Temperature annual range (bio5 - bio6) \\
bio8 & Mean temperature of wettest quarter \\
bio9 & Mean temperature of driest quarter \\
bio10 & Mean temperature of warmest quarter \\
bio11 & Mean temperature of coldest quarter \\
bio12 & Annual precipitation \\
bio13 & Precipitation of wettest month \\
bio14 & Precipitation of driest month \\
bio15 & Precipitation seasonality (coefficient of variation) \\
bio16 & Precipitation of wettest quarter \\
\hline Pio18 & Precipitation of driest quarter \\
\hline Precipitation of coldest quarter \\
Altitude
\end{tabular}

Tab. 3 The AUC scores for each model created during the study with information on standard deviation values $(S D)$.

\begin{tabular}{llll} 
& All locations & $\begin{array}{l}\text { African } \\
\text { locations only }\end{array}$ & $\begin{array}{l}\text { Neotropical } \\
\text { locations only }\end{array}$ \\
\hline Present time & $\begin{array}{l}0.974 \\
(S D=0.005)\end{array}$ & $\begin{array}{l}0.972 \\
(S D=0.012)\end{array}$ & $\begin{array}{l}0.984 \\
(S D=0.004)\end{array}$ \\
& & & \\
LGM & 0.979 & 0.973 & 0.982 \\
& $(S D=0.005)$ & $(S D=0.012)$ & $(S D=0.005)$ \\
& & & \\
\hline
\end{tabular}

were covered during LGM with seasonal tropical forest as well as with tropical savanna and woodland [34].

\section{Current potential range}

The combined model (95\% confidence level summary grids, Fig. $3 a-c)$ of suitable habitats created using all available location data shows the general decreasing of the available niches in Neotropics and increasing of the African ones in comparison with the analogical models for LGM. In South America the highest concentration of proper niches is observed near the estuaries of Orinoco and Amazon rivers as well as in Cachimbo and dos Gradaús mountains. Less suitable areas are located in the lowland between Andes and Amazon basin. The African niches seem extended within the tropical Africa to east, but their general distribution did not change.

\section{Niches overlap and identity}

The calculated statistics confirm the geographical differences in the distribution of the suitable niches for African and Neotropical populations of $E$. alta $(D=0.319 ; I=0.587)$, however the niche identity test indicate moderate similarity between the preferred habitats $[D=0.657(S D=0.0609)$; $I=0.883(S D=0.036)]$. The overlap of models created for LGM and present time created based all known locations of E. alta gave results of $D=0.800$ and $I=0.947$.

\section{Discussion}

\section{Ecological niches distribution vs. current range}

The known geographical range of E. alta corresponds to the distribution of its suitable niches estimated in ENM analysis. The only areas where there are no proper niches for the studied species, according to the ecological model, and where the specimens of the studied orchid were found, are southern Florida and northern Cuba. The first region is significantly affected by non-native plants, which are naturalized from the horticultures, and it can be hypothesized that the ornamental usage of E. alta is the source of its North American populations [35]. The most probable reason of the occurrence of this orchid in Cuba is the migration of E. alta from other Caribbean islands. As it was shown in the previous studies the invasive populations may shift their niches to invade new areas $[18,36]$. As the Neotropical populations of E. alta often grow in disturbed, open areas, such as roadsides, their ecological amplitude is rather wide and it was confirmed in the ENM analysis. Hereby the chances of the North American populations to survive in habitats

Tab. 4 Relative contributions of the environmental variables to the Maxent models.

\begin{tabular}{lcccc} 
& \multicolumn{2}{c}{ African locations only } & Neotropical locations only \\
\hline Present time & biol1 (46.5\%) & bio4 $(32.6 \%)$ & bio4 (35.5\%) & bio19 (14\%) \\
LGM & bio4 (36.9\%) & bio11 (36.1\%) & bio4 (35.5\%) & bio19(14.7\%)
\end{tabular}




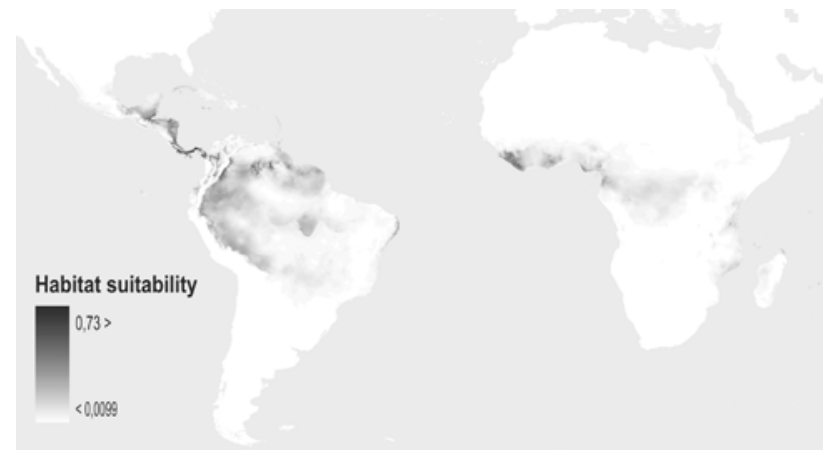

Fig. 2 The Maxent projections of suitable habitats of E. alta onto climatic conditions of LGM derived from Paleoclimate Modelling Intercomparison Project Phase II.

less suitable for the studied orchid are high. Unfortunately, the number of the known locations of E. alta in this region is not sufficient to conduct reliable analysis of their ecology and to verify the possible niche shift of those populations.

\section{African vs. Neotropical niches}

The differences between niches occupied by African and Neotropical populations of E. alta suggest preglacial disjunction of its range and gradual, independent adaptation of both groups to slightly different climatic conditions. This timing is indicated by the consistency of the glacial refugia of this orchid in Africa and Neotropics with its current distribution that confirm the postglacial migration of this orchids on different continents from the refugia defined in the ENM analysis. Nevertheless, the occurrence of adaptation processes requires confirmation in the genetic studies. Apparently the climate changes during LGM were more harmful for African populations and while E. alta is now common in Neotropics, its African potential range declined.

\section{Niche conservatism}

While numerous species shift their niches in response to warming climate after the last glacial maximum [37-39], the habitats suitable for E. alta seem to be rather stable as indicated by the niche overlap test for LGM and present time. Considering also the relative similarity of the suitable niches and limiting factors for E. alta populations from different continents the phylogenetic niche conservatism theory seems

\section{Acknowledgments}

The curators and staff of the cited herbaria are thanked for their kind hospitality and assistance during visits and for making specimens available on loan. Research was supported financially by the Ministry of Science and Higher Education of Poland (grant No. 8124/B/PO1/2011/40).

\section{Authors' contributions}

The following declarations about authors' contributions to the research have been made: research designing, conducting experiments, writing the manuscript (except "Introduction" section), appendices and figures preparation: MK; location database preparation,
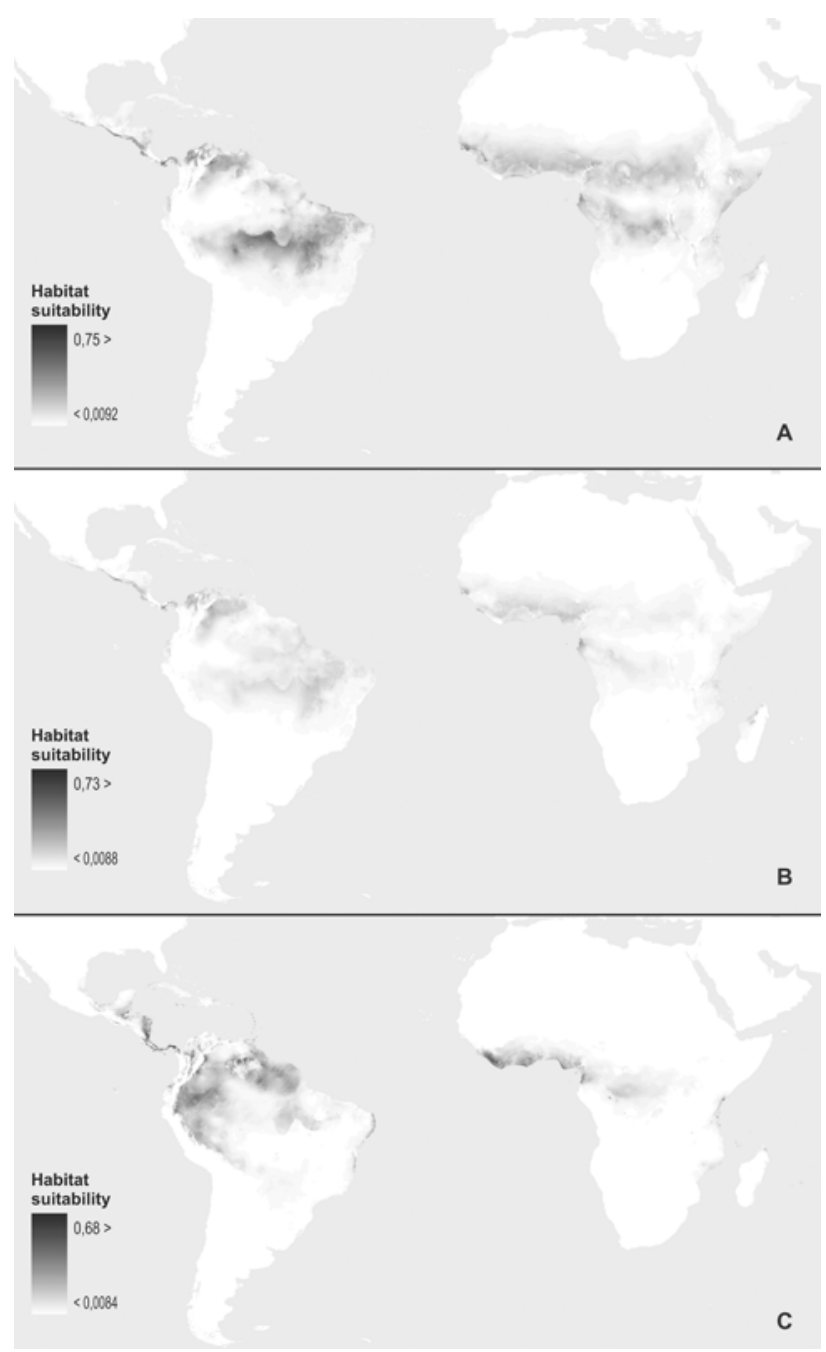

Fig. 3 The Maxent projections of suitable habitats of E. alta based on all localities (a), African localities only (b), Neotropical localities only (c).

to be applicable to the evolution history or this species. Despite the significant geographical disjunction of E. alta a high degree of its fundamental niche conservatism was found. This is also implied by the morphological uniformity of species representatives that suggest lack of substantial, abrupt adaptation to distinct habitat conditions.

herbarium specimens examination, taxonomic information on the study object, writing the manuscript ("Introduction" section): DLS.

\section{References}

1. Renner S. Plant dispersal across the tropical Atlantic by wind and sea currents. Int J Plant Sci. 2004;165(S4):S23-S33. http://dx.doi. org/10.1086/383334

2. Thorne RF. Floristic relationships between tropical Africa and tropical America. In: Meggers BJ, Ayensu ES, Duckworth WD, editors. Tropical forest ecosystems in Africa and South America: a comparative review. Washington, WA: Smithsonian Institution; 1973. p. 27-47. 
3. Manchester SR. Biogeographical relationships of North American Tertiary floras. Ann Mo Bot Gard. 1999;86(2):472-522. http://dx.doi. org/10.2307/2666183

4. Thulin M, Thiede J, Liede-Schumann S. Phylogeny and taxonomy of Tribulocarpus (Aizoaceae): a paraphyletic species and an adaptive shift from zoochorous trample burrs to anemochorous nuts. Taxon. 2012;61(1):55-66.

5. Rödder D, Lötters S. Niche shift or niche conservatism? Climatic properties of the native and invasive range of the Mediterranean Housegecko Hemidactylus turcicus. Glob Ecol Biogeogr. 2009;18(6):674-687. http://dx.doi.org/10.1111/j.1466-8238.2009.00477.x

6. Cooper N, Freckleton RP, Jetz W. Phylogenetic conservatism of environmental niches in mammals. Proc R Soc B. 2011;278(1716):23842391. http://dx.doi.org/10.1098/rspb.2010.2207

7. Ryan Shipley J, Contina A, Batbayar N, Bridge ES, Peterson AT, Kelly JF. Niche conservatism and disjunct populations: a case study with Painted Buntings (Passerina ciris). Auk. 2013;130(3):476-486. http:// dx.doi.org/10.1525/auk.2013.12151

8. Crisp MD, Cook LG. Phylogenetic niche conservatism: what are the underlying evolutionary and ecological causes? New Phytol. 2012;196(3):681-694. http://dx.doi. org/10.1111/j.1469-8137.2012.04298.x

9. Algar AC, Kerr JT, Currie DJ. Evolutionary constraints on regional faunas: whom, but not how many. Ecol Lett. 2009;12(1):57-65. http:// dx.doi.org/10.1111/j.1461-0248.2008.01260.x

10. Wiens JJ, Donoghue MJ. Historical biogeography, ecology and species richness. Trends Ecol Evol. 2004;19(12):639-644. http://dx.doi. org/10.1016/j.tree.2004.09.011

11. Wiens JJ, Graham CH. Niche conservatism: integrating evolution, ecology, and conservation biology. Annu Rev Ecol Evol Syst. 2005;36(1):519-539. http://dx.doi.org/10.1146/annurev. ecolsys.36.102803.095431

12. Wiens JJ, Ackerly DD, Allen AP, Anacker BL, Buckley LB, Cornell $\mathrm{HV}$, et al. Niche conservatism as an emerging principle in ecology and conservation biology: niche conservatism, ecology, and conservation. Ecol Lett. 2010;13(10):1310-1324. http://dx.doi. org/10.1111/j.1461-0248.2010.01515.x

13. Losos JB. Phylogenetic niche conservatism, phylogenetic signal and the relationship between phylogenetic relatedness and ecological similarity among species. Ecol Lett. 2008;11(10):995-1003. http:// dx.doi.org/10.1111/j.1461-0248.2008.01229.x

14. Lindqvist C, Albert VA. Origin of the Hawaiian endemic mints within North American Stachys (Lamiaceae). Am J Bot. 2002;89(10):1709_ 1724. http://dx.doi.org/10.3732/ajb.89.10.1709

15. Spalik K, Downie SR. Intercontinental disjunctions in Cryptotaenia (Apiaceae, Oenantheae): an appraisal using molecular data. J Biogeogr. 2007;34(12):2039-2054. http://dx.doi. org/10.1111/j.1365-2699.2007.01752.x

16. Duchen P, Renner SS. The evolution of Cayaponia (Cucurbitaceae): repeated shifts from bat to bee pollination and long-distance dispersal to Africa 2-5 million years ago. Am J Bot. 2010;97(7):1129-1141. http://dx.doi.org/10.3732/ajb.0900385

17. Jurgens A, Bosch SR, Webber AC, Witt T, Frame D, Gottsberger G. Pollination biology of Eulophia alta (Orchidaceae) in Amazonia: effects of pollinator composition on reproductive success in different populations. Ann Bot. 2009;104(5):897-912. http://dx.doi.org/10.1093/ aob/mcp 191

18. Kolanowska M. Niche conservatism and the future potential range of Epipactis helleborine (Orchidaceae). PLoS ONE. 2013;8(10):e77352. http://dx.doi.org/10.1371/journal.pone.0077352

19. Kolanowska M, Konowalik K. Niche conservatism and future changes in the potential area coverage of Arundina graminifolia, an invasive orchid species from Southeast Asia. Biotropica. 2014;46(2):157-165. http://dx.doi.org/10.1111/btp.12089
20. Kolanowska M. Glacial refugia and migration routes of the Neotropical genus Trizeuxis (Orchidaceae). Acta Soc Bot Pol. 2013;82(3):225-230. http://dx.doi.org/10.5586/asbp.2013.024

21. Thiers B. Index Herbariorum: a global directory of public herbaria and associated staff. New York Botanical Garden's Virtual Herbarium [Internet]. 2013 [cited 2013 Jan 10]; Available from: http://sweetgum. nybg.org/ih/

22. Hijmans RJ, Schreuder M, de la Cruz J, Guarino L. Using GIS to check co-ordinates of genebank accessions. Genet Resour Crop Evol. 1999;46(3):291-296. http://dx.doi.org/10.1023/A:1008628005016

23. Pearson RG, Raxworthy CJ, Nakamura M, Townsend Peterson A. Predicting species distributions from small numbers of occurrence records: a test case using cryptic geckos in Madagascar: predicting species distributions with low sample sizes. J Biogeogr. 2006;34(1):102-117. http://dx.doi.org/10.1111/j.1365-2699.2006.01594.x

24. Elith J, Phillips SJ, Hastie T, Dudík M, Chee YE, Yates CJ. A statistical explanation of MaxEnt for ecologists: statistical explanation of MaxEnt. Divers Distrib. 2011;17(1):43-57. http://dx.doi. org/10.1111/j.1472-4642.2010.00725.x

25. Phillips SJ, Dudík M, Schapire RE. A maximum entropy approach to species distribution modeling. In: ICML '04: proceedings of the twenty-first international conference on machine learning. New York, NY: ACM; 2004. p. 655-662.

26. Phillips SJ, Anderson RP, Schapire RE. Maximum entropy modeling of species geographic distributions. Ecol Modell. 2006;190(3-4):231-259. http://dx.doi.org/10.1016/j.ecolmodel.2005.03.026

27. Rodríguez-Robles JA, Jezkova T, Leal M. Climatic stability and genetic divergence in the tropical insular lizard Anolis krugi, the Puerto Rican 'Lagartijo Jardinero de la Montaña. Mol Ecol. 2010;19(9):1860-1876. http://dx.doi.org/10.1111/j.1365-294X.2010.04616.x

28. Kuemmerle T, Hickler T, Olofsson J, Schurgers G, Radeloff VC. Reconstructing range dynamics and range fragmentation of European bison for the last 8000 years: European bison range dynamics. Divers Distrib. 2012;18(1):47-59. http://dx.doi.org/10.1111/j.1472-4642.2011.00849.x

29. Hijmans RJ, Cameron SE, Parra JL, Jones PG, Jarvis A. Very high resolution interpolated climate surfaces for global land areas. Int J Clim. 2005;25(15):1965-1978. http://dx.doi.org/10.1002/joc.1276

30. Braconnot P, Otto-Bliesner B, Harrison S, Joussaume S, Peterchmitt JY, Abe-Ouchi A, et al. Results of PMIP2 coupled simulations of the mid-holocene and last glacial maximum - part 1: experiments and large-scale features. Clim Past. 2007;3(2):261-277. http://dx.doi. org/10.5194/cp-3-261-2007

31. Urbina-Cardona JN, Loyola RD. Applying niche-based models to predict endangered-hylid potential distributions: are neotropical protected areas effective enough. Trop Conserv Sci. 2008;1(4):417-445.

32. Schoener TW. The anolis lizards of bimini: resource partitioning in a complex fauna. Ecology. 1968;49(4):704-726. http://dx.doi. org/10.2307/1935534

33. Warren DL, Glor RE, Turelli M. Environmental niche equivalency versus conservatism: quantitative approaches to niche evolution. Evolution. 2008;62(11):2868-2883. http://dx.doi. org/10.1111/j.1558-5646.2008.00482.x

34. Olson JS, Watts JA, Allison LJ. Carbon in live vegetation of major world ecosystems. Report DOE/NBB-0037 for US Dept. of Energy. Washington, WA: Carbon Dioxide Research Division; 1983.

35. Stewart SL, Johnson TR, Dutra D, Kane M, Richardson L. Ecology, propagation and conservation of Eulophia alta L., a threatened Florida orchid. Gainesville, FL: Florida Cooperative Fish and Wildlife Research Unit; 2007. 
36. Angetter LS, Lötters S, Rödder D. Climate niche shift in invasive species: the case of the brown anole. Biol J Linn Soc Lond. 2011;104(4):943954. http://dx.doi.org/10.1111/j.1095-8312.2011.01780.x

37. Thuiller W. Patterns and uncertainties of species' range shifts under climate change. Glob Chang Biol. 2004;10(12):2020-2027. http:// dx.doi.org/10.1111/j.1365-2486.2004.00859.x

38. Jezkova T, Olah-Hemmings V, Riddle BR. Niche shifting in response to warming climate after the last glacial maximum: inference from genetic data and niche assessments in the chisel-toothed kangaroo rat (Dipodomys microps). Glob Chang Biol. 2011;17(11):3486-3502. http://dx.doi.org/10.1111/j.1365-2486.2011.02508.x

39. Veloz SD, Williams JW, Blois JL, He F, Otto-Bliesner B, Liu Z. Noanalog climates and shifting realized niches during the late quaternary: implications for 21st-century predictions by species distribution models. Glob Chang Biol. 2012;18(5):1698-1713. http://dx.doi. $\operatorname{org} / 10.1111 / \mathrm{j} .1365-2486.2011 .02635 . x$ 